\title{
CHEMICAL CONSTITUENTS OF METHANOLIC EXTRACTS OF Jatropha curcas L AND EFFECTS ON Spodoptera frugiperda (J. E. Smith) (Lepidoptera: Noctuidae) $)^{\#}$
}

\author{
Sandra Santos Ribeiro, Thanany Brasil da Silva, Valéria Regina de Souza Moraes, Paulo Cesar de Lima Nogueira e \\ Emmanoel Vilaça Costa \\ Departamento de Química, Universidade Federal de Sergipe, 49100-000 São Cristóvão - SE, Brasil \\ Antônio Rogério Bernardo, Andreia Pereira Matos, João Batista Fernandes* e Maria Fátima das Graças Fernandes da Silva \\ Departamento de Química, Universidade Federal de São Carlos, 13565-905 São Carlos - SP, Brasil \\ Ângela Maria dos Santos Pessoa e Renata Silva-Mann \\ Departamento de Engenharia Agronômica, Universidade Federal de Sergipe, 49100-000 São Cristóvão - SE, Brasil
}

Recebido em 14/5/12; aceito em 5/8/12; publicado na web em 26/10/12

\begin{abstract}
The biological activity of seven extracts from leaves of different Jatropha curcas L (Euphorbiaceae) accessions was evaluated on Spodoptera frugiperda. Methanol extracts were incorporated into an artificial diet and offered to the larval stage of $S$. frugiperda. The parameters evaluated were length of larval and pupal stages, mortality of larval and total cycle stage, and weight of pupae. The extracts of the EMB accessions showed the best result for larval mortality at 60.00 and $56.67 \%$, compared with the control, respectively. Hexane partition of the methanol extract of the leaves of PM-14 accessions allowed the identification of phytosterols, phytol and n-alkanols.
\end{abstract}

Keywords: Jatropha curcas; fall armyworm; insecticide activity.

\section{INTRODUCTION}

The fall armyworm Spodoptera frugiperda (J. E. Smith) (Lepidoptera: Noctuidae) is the most prevalent pest in corn crops and can reduce corn production by up to $34 \%$, depending at which cultivation growth stage the attack occurs. ${ }^{1}$ Fall armyworm larvae are usually controlled using pesticides such as piretroids and organophosphates when defoliation is noted in the field. ${ }^{2}$ However, there are many problems associated with the use of pesticides, mainly the possibility of resistance, reduction of insect predators and parasitoids that interfere in natural control. ${ }^{1} \mathrm{New}$ alternatives must be pursued including botanical insecticides. These insecticides of botanical origin may represent an effective alternative to persistent synthetic insecticides, since their advantages are low mammalian toxicity, lack of neurotoxic action, low persistence in the environment and high biodegrability. ${ }^{3}$

The family Euphorbiaceae contain toxic compounds that can be used as insecticides. ${ }^{4}$ The Jatropha curcas species (Malpighiales: Euphorbiaceae) is a drought-resistant shrub that is well adapted to arid and semi-arid conditions, being a viable plant for family agriculture in the North and Northeast regions of Brazil. Furthermore, this plant has a high agro-industrial potential because the oil extracted from its seeds can be used for biodiesel production. ${ }^{5}$

The seeds of $J$. curcas are toxic to both humans and animals precluding their use in foodstuffs. ${ }^{6}$ This toxicity of the seed is attributed predominantly to the phorbol-type diterpene esters which they contain at high concentrations. ${ }^{7}$ Previous studies on leaves of this plant have investigated the isolation of flavonoids, ${ }^{8}$ sterols, ${ }^{9}$ polyprenols, ${ }^{10}$ besides saprophytic fungal activity, ${ }^{11}$ larvicidal activity, ${ }^{12}$ and molluscicidal activity. ${ }^{13}$ As a part of an ongoing study toward biorational control of $S$. frugiperda,${ }^{14}$ the aim of the present work was to chemically investigate and evaluate the insecticidal activity

*e-mail: djbf@ufscar.br

\#Artigo em homenagem ao Prof. Otto R. Gottlieb (31/8/1920-19/6/2011) of extracts from the leaves of $J$. curcas accession (bout) against the larvae of fall armyworm under laboratory conditions.

\section{EXPERIMENTAL}

\section{Botanical material}

Leaves of six accessions, named PM-2, PM-7, PM-10, PM-11, PM-12 and PM-14, of Jatropha curcas L. were collected in January 2009 (for fresh leaf studies) and March 2009 (for air-dried leaf studies), from the Germoplasm Bank of the Agronomic Engineering Department of the Federal University of Sergipe, São Cristóvão, Brazil. Leaves of an accession of a J. curcas specimen (called EMB) were collected in October 2008, from the Experimental Campus of the "Embrapa Tabuleiros Costeiros", in the Municipality of Umbaúba, Sergipe, Brazil. A voucher specimen (JC014URVES) was deposited at the Federal University of Sergipe Herbarium in the Biology Department.

\section{Preparation of the extracts}

Leaves, air-dried by 5 days, and fresh leaves of each $J$. curcas accession were triturated and extracted separately at room temperature with methanol $(1: 4 \mathrm{w} / \mathrm{v})$ by maceration for 5 days. The solutions obtained were filtrated through analytical filter papers and solvents removed under reduced pressure to give the correspondent crude extracts of fresh and air-dried leaves (Table 1). The extraction steps for each accession were repeated twice.

\section{Isolation and identification of the chemical constituents}

Part of the crude leaf methanol extract (5.02 g) from PM-14 J. curcas accession was suspended in $150 \mathrm{~mL}$ of a solution containing MeOH: $\mathrm{H}_{2} \mathrm{O}$ (9:1) and extracted successively with hexane $(3 \times 150$ $\mathrm{mL}), \mathrm{CH}_{2} \mathrm{Cl}_{2}(2 \times 150 \mathrm{~mL})$, and EtOAc $(3 \times 100 \mathrm{~mL})$ yielding 0.67 , 0.29 and $0.11 \mathrm{~g}$ of the respective partitions and the hydroalcoholic 
Table 1. Methanolic extracts prepared from fresh and dried leaves of $J$. curcas accessions

\begin{tabular}{lcccc}
\hline \multirow{2}{*}{ Accession } & \multicolumn{2}{c}{ Fresh leaves } & \multicolumn{2}{c}{ Dried leaves } \\
\cline { 2 - 5 } & $\begin{array}{c}\text { Plant mass } \\
(\mathrm{g})\end{array}$ & $\begin{array}{c}\text { Extract mass } \\
(\mathrm{g})\end{array}$ & $\begin{array}{c}\text { Plant mass } \\
(\mathrm{g})\end{array}$ & $\begin{array}{c}\text { Extract mass } \\
(\mathrm{g})\end{array}$ \\
\hline PM-2 & 227.7 & 10.7 & 123.8 & 10.9 \\
PM-7 & 87.7 & 4.6 & 123.7 & 4.6 \\
PM-10 & 179.0 & 5.1 & 242.1 & 12.6 \\
PM-11 & 271.8 & 8.7 & 149.3 & 9.4 \\
PM-12 & 249.2 & 7.8 & 134.3 & 9.4 \\
PM-14 & 233.0 & 3.7 & 185.7 & 9.8 \\
EMB & 83.4 & 2.6 & 127.5 & 6.3 \\
\hline
\end{tabular}

extract (1.35 g), after solvent evaporation. Part of this hexane partition $(0.4 \mathrm{~g})$ was subjected to silica gel column chromatography, eluting with hexane, EtOAc and $\mathrm{MeOH}$ in a gradient manner to yield thirty-eight subfractions. The eleventh fraction $(31.9 \mathrm{mg})$ was further purified by preparative thin-layer chromatography (TLC) with hexane-EtOAc (90:10, v/v) and 10 drops of $\mathrm{MeOH}$ as the mobile phase to yield the fraction $1(14.9 \mathrm{mg})$. Following the same procedure, the seventh fraction $(20.0 \mathrm{mg}$ ) was further purified by preparative thin-layer chromatography (TLC) with hexane-EtOAc (90:10, v/v) as the mobile phase to yield fraction 2 ( $4 \mathrm{mg}$ ).

Fractions 1 and 2 were investigated by gas chromatography-mass spectrometry (GC/MS) and the compounds 1-3 (fraction 1) and 4-7 (fraction 2) were identified in these fractions. Analysis was carried out on a Shimadzu QP5050A device with a capillary column DB5-MS (30 m x $0.25 \mathrm{~mm}, 0.25 \mu \mathrm{m}$ film thickness). Temperature program: $180{ }^{\circ} \mathrm{C}$ (held for $1 \mathrm{~min}$ ) to $300{ }^{\circ} \mathrm{C}$ at a heating rate of $20{ }^{\circ} \mathrm{C} \mathrm{min}-1$ (held for $5 \mathrm{~min}$ ), then raised from 300 to $320{ }^{\circ} \mathrm{C}$ at a heating rate of $5^{\circ} \mathrm{C} \mathrm{min}{ }^{-1}$ (held for $10 \mathrm{~min}$ ). Helium was used as the carrier gas. The interface was set at $280{ }^{\circ} \mathrm{C}$ and the ionization voltage was $70 \mathrm{eV}$ (electron impact mode). Fractions 1 and 2 were also analyzed by ${ }^{1} \mathrm{H}$ and ${ }^{13} \mathrm{C}$ NMR spectroscopy on a BRUKER DRX 400 device using $\mathrm{CDCl}_{3}$ as a solvent and TMS as an internal standard.

\section{Derivatization}

For the silylation reaction, $100 \mu \mathrm{L}$ of N,O-Bis(trimethylsilyl) trifluoroacetamide (BSTFA, $>99 \%$ Sigma-Aldrich) was added to fraction 2 and then left at room temperature $\left(\sim 30^{\circ} \mathrm{C}\right)$ for $1 \mathrm{~h}$. The residue was taken up in $250 \mu \mathrm{L}$ of dichloromethane and then analyzed by GC/MS. The identification of silyl derivatives was performed by comparison with reported mass spectra, interpretation of fragmentation patterns and gas chromatographic retention indices. ${ }^{15,16}$

\section{Biological bioactivity}

Larvae of S. frugiperda were obtained from the Insect Bioassay Laboratory of the Federal University of São Carlos, Brazil, and reared on artificial diets. ${ }^{17,18}$ They were maintained in an incubation chamber with a light phase of 12:12 h L:D, $70 \pm 5 \%$ relative humidity and temperature of $25 \pm 1{ }^{\circ} \mathrm{C}$. For each treatment and control, 30 neonate larvae of $S$. frugiperda were used. The methanolic extracts were added to ascorbic acid (1.56 g; an ingredient of the diet). After evaporation, the mixture was incorporated into the artificial diet in which bean and wheat germ were the basic ingredients ${ }^{17}$ at a final content of $1000 \mathrm{mg}$ $\mathrm{kg}^{-1}$ for the methanolic extract of $J$. curcas. The diet for the control larvae was prepared similarly but with no extract. The diets were placed in previously sterilized glass tubes $(8.5 \mathrm{~cm} 2.5 \mathrm{~cm})$ into which larvae of S. frugiperda were introduced individually. The resultant pupae were weighed after pupation and transferred into plastics cups, where they were kept until the emergence of adults. Daily observations were made and the following parameters evaluated: duration of larval and pupal phases; weight of pupae and percentage of dead insects (mortality) at the end of each phase.

\section{Statistics}

Data were submitted to analysis of variance ANOVA $^{19}$ and averages were compared by applying the Tukey test $(P \leq 0.05)$. Each tube containing one insect, independent of the development phase, was considered as one replicate therefore the number of replicates was different for each treatment. For evaluation of the mortality of the larval and pupal phases, the experimental unit constituted the mean of five tubes containing one larva each, with thirty replications per treatment.

\section{RESULTS AND DISCUSSION}

The analysis of fraction 1 by ${ }^{1} \mathrm{H}$ and ${ }^{13} \mathrm{C} \mathrm{NMR}^{20}$ and GC/MS ${ }^{21}$ led to the identification of a mixture of the three known phytosterols campesterol (1), stigmasterol (2) and $\beta$-sitosterol (3) (Figure 1), which were similar to those found by Hufford and Oguntimein. ${ }^{9}$
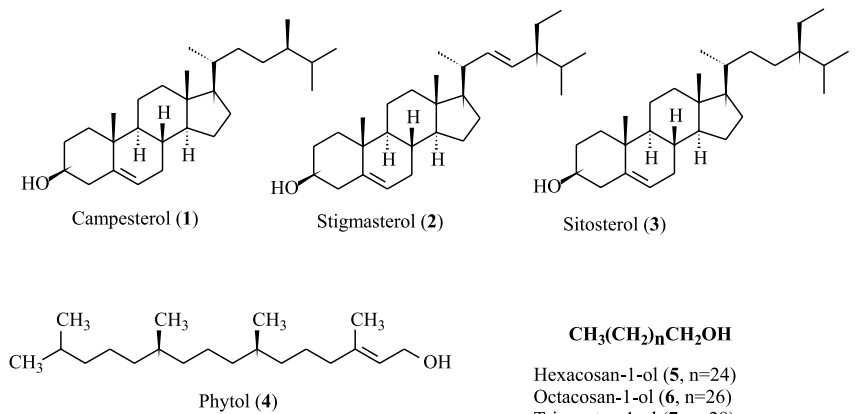

\section{$\mathrm{CH}_{3}\left(\mathrm{CH}_{2}\right)_{\mathrm{n}} \mathrm{CH}_{2} \mathrm{OH}$}

Hexacosan-1-ol $(\mathbf{5}, \mathrm{n}=24)$ Octacosan-1-ol $(\mathbf{6}, \mathrm{n}=26)$ Triacontan-1-ol $(7, \mathrm{n}=28)$

Figure 1. Compounds isolated from leaves of Jatropha curcas $L$.

The identification of compounds from fraction 2 was based on characteristic mass spectra fragmentation patterns of trimethylsilyl (TMS) ether derivatives of the phytol (4) and alcohols, by comparing the retention times and mass spectrum of an authentic sample. The EI spectra of their TMS derivatives were identical to those of phytol (4), hexacosan-1-ol (5), octacosan-1-ol (6) and triacontan-1-ol (7) (Figure 1), respectively as was their retention index, generated with a standard solution of n-alkanes $\left(\mathrm{C}_{9}-\mathrm{C}_{40}\right) \cdot{ }^{15,22}$

Methanolic extractions were conducted with fresh and air-dried leaves (Table 1). Among the extracts of fresh leaf accessions tested, only PM-12 and PM-14 revealed a statistical difference in relation to the control. There was a shortening of 2.80 days in larval stage for PM-12 and 1.06 days in pupal stage for PM-14, in comparison with the control treatment, whose larval and pupal stages were 21.70 and 11.77 days, respectively. No statistically significant changes in pupal weight and mortality were found in relation to the control (data not shown). The EMB accession had the highest mortality in the larval stage $(60 \%)$ compared to the control while the other accessions showed from moderate (16.66 to $13.33 \%$ ) to low activity (10.00 to $3.33 \%$, Table 2).

The period of larval stage submitted to methanolic extracts of airdried leaves of the $J$. curcas accessions showed statistically moderate difference for PM-2, PM-7, PM-10 and PM-11, being 2.44, 2.18 and 2.49 days shorter than the control, respectively. Pupal period was similar to the control whereas pupal mortality showed no statistically 
Table 2. Mean of larval and pupal period and larval mortality of S. frugiperda fed on artificial diet treated with bouts of fresh leaves, $1000 \mathrm{mg} \mathrm{kg}^{-1}$, of $J$. curcas. Temp.: $25 \pm 1{ }^{\circ} \mathrm{C}$; UR: $70 \pm 5 \%$ and photophase: $12 \mathrm{~h}$

\begin{tabular}{|c|c|c|c|c|}
\hline Treatment & & Larval period (days) $( \pm \mathrm{EP})^{1}$ & Pupal period (days) $( \pm \mathrm{EP})^{1}$ & Larval mortality $(\%)( \pm \mathrm{EP})^{1}$ \\
\hline \multirow[t]{7}{*}{ Jatropha curcas Fresh leaves } & PM-2 & $20.00 \pm 1.95 b c$ & $11.70 \pm 1.03 a b$ & $3.33 \pm 5.77 b$ \\
\hline & PM-7 & $19.00 \pm 0.91 \mathrm{bc}$ & $11.54 \pm 1.14 \mathrm{ab}$ & $10.00 \pm 10.00 \mathrm{~b}$ \\
\hline & PM-10 & $20.38 \pm 2.80 \mathrm{~b}$ & $11.64 \pm 0.90 \mathrm{ab}$ & $13.33 \pm 5.77 \mathrm{~b}$ \\
\hline & PM-11 & $19.33 \pm 1.04 \mathrm{bc}$ & $11.62 \pm 1.13 \mathrm{ab}$ & $10.00 \pm 10.00 \mathrm{~b}$ \\
\hline & PM-12 & $18.90 \pm 1.01 \mathrm{c}$ & $11.04 \pm 1.14 \mathrm{ab}$ & $3.33 \pm 5.77 b$ \\
\hline & PM-14 & $20.00 \pm 1.19 b c$ & $10.71 \pm 1.40 \mathrm{~b}$ & $16.67 \pm 15.28 b$ \\
\hline & EMB & $22.58 \pm 2.54 \mathrm{a}$ & $11.91 \pm 1.22 \mathrm{ab}$ & $60.00 \pm 20.00 \mathrm{a}$ \\
\hline Control & & $21.70 \pm 2.15 \mathrm{ab}$ & $11.77 \pm 0.99 \mathrm{a}$ & $0.00 \pm 0.00 \mathrm{~b}$ \\
\hline
\end{tabular}

${ }^{1}$ Means followed by same letter in column do not differ by Tukey test $(\mathrm{P} \leq 0.05)$.

Table 3. Mean of larval and pupal period and larval mortality of S. frugiperda fed on artificial diet treated with bouts of air-dried leaves, $1000 \mathrm{mg} \mathrm{kg}^{-1}$, of $J$. curcas. Temp.: $25 \pm 1{ }^{\circ} \mathrm{C}$; UR: $70 \pm 5 \%$ and photophase: $12 \mathrm{~h}$

\begin{tabular}{|c|c|c|c|c|}
\hline Treatment & & Larval period (days) $( \pm \mathrm{EP})^{1}$ & Pupal period (days) $( \pm \mathrm{EP})^{1}$ & Larval mortality $(\%)( \pm \mathrm{EP})^{1}$ \\
\hline \multirow[t]{7}{*}{ Jatropha curcas Air-dried fresh } & PM-2 & $19.26 \pm 2.28 b$ & $10.96 \pm 1.10 \mathrm{~b}$ & $10.00 \pm 10.00 \mathrm{bc}$ \\
\hline & PM-7 & $19.52 \pm 1.47 \mathrm{~b}$ & $11.71 \pm 2.15 \mathrm{ab}$ & $13.33 \pm 15.27 b$ \\
\hline & PM-10 & $19.26 \pm 1.13 b$ & $12.27 \pm 1.23 \mathrm{a}$ & $30.00 \pm 0.00 \mathrm{~b}$ \\
\hline & PM-11 & $19.21 \pm 1.64 \mathrm{~b}$ & $11.81 \pm 1.33 \mathrm{ab}$ & $10.00 \pm 0.00 \mathrm{bc}$ \\
\hline & PM-12 & $20.33 \pm 1.15 \mathrm{ab}$ & $11.15 \pm 1.29 \mathrm{ab}$ & $6.67 \pm 5.77 \mathrm{c}$ \\
\hline & PM-14 & $22.15 \pm 2.03 \mathrm{a}$ & $11.12 \pm 1.25 \mathrm{ab}$ & $60.00 \pm 10.00 \mathrm{a}$ \\
\hline & EMB & $19.52 \pm 1.47 \mathrm{~b}$ & $11.36 \pm 1.21 \mathrm{a}$ & $56.67 \pm 5.77 \mathrm{a}$ \\
\hline Control & & $21.70 \pm 2.15 \mathrm{a}$ & $11.77 \pm 0.99 a b$ & $0.00 \pm 0.00 \mathrm{c}$ \\
\hline
\end{tabular}

${ }^{1}$ Means followed by same letter in column do not differ by Tukey test $(\mathrm{P} \leq 0.05)$.

significant difference. The larval mortality was higher for accessions EMB, PM-14 and PM-10 (56.67, 60.00 and $30.00 \%$, respectively), compared to the control $(0.00 \%)$ (Table 3$)$.

In a previous study, Devanand and Rani tested ketone extracts of leaves of J. curcas and other species of Euphorbiaceae, Myrtaceae and Rutaceae families. ${ }^{23}$ Their results have proven that the species $J$. curcas has a significant anti-feeding activity in Achaea janata L. (greater than 90\%) and moderate in Spodoptera litura Fab. (52\%). The mean (\%) toxicity \pm SD of this extract was $36.6+/-4.7$ and 60.6 +/- 60.6 in S. litura and A. janata, respectively and $\mathrm{LD}_{50}(95 \% \mathrm{CL}$, $\mathrm{mg} / 21 \mathrm{~cm}^{2} /$ larva) were higher than 100 for both assays. ${ }^{23}$ Based on the results of the cited study and activity observed in the present work, $J$. curcas can be classified as a good alternative for integrated pest management due to its toxic and antifeeding properties for several species of pests and minimum environmental impact. Thorough chemical fractionation of active extract and development of a methodology to apply crude extract of $J$. curcas are underway and is hoped to reveal some bioactive compounds and a methodology for using crude extract to control plague insects.

\section{ACKNOWLEDGEMENTS}

This research received partial support from CNPq (Conselho Nacional de Desenvolvimento Científico e Tecnológico) - (Brazilian government entity promoting the scientific and technological development), FAPESP (Fundação de Amparo à Pesquisa do Estado de São Paulo), FAPITEC/SE (Fundação de Apoia à Pesquisa e à Inovação Tecnológica do Estado de Sergipe), and CAPES/PROCAD. The authors are grateful to Prof. Dr. M. da R. Alexandre (DQI/UFS) who kindly provided the BSTFA reagent for silylation and a sample of n-alkanes for the retention index calculation.

\section{REFERENCES}

1. Cruz, I.; Sete Lagoas, Embrapa/CNPMS, 1995, Circular Técnica, n. 21.

2. Jesus, F. L.; Boiça Jr., A. L. In Tópicos em Entomologia Agrícola II; Silva, A. G.; Rodrigues, C. A.; Becaro, C. K.; Bottega, D. B.; Haddad, G. K.; Alvez, G. C. S.; Janini, J. C., eds.; Funep: Jaboticabal, 2009.

3. Céspedes, C. L.; Calderón, J. S.; Lina, L.; Aranda, E.; J. Agric. Food Chem. 2000, 48, 1903; Céspedes, C. L.; Salazar, J. R.; Martínez, M.; Aranda E.; Phytochemistry 2005, 66, 2481.

4. Cruz, I.; Viana, P. A.; Waquil, J. M.; Sete Lagoas, Embrapa/CNPMS, 2002, Comunicado Técnico, n. 49.

5. Jain, P. S.; Sharma, M. P.; Ren. Sust. Energ. Rev. 2010, 14, 3140; Suarez, P. A. Z.; Santos, A. L. F.; Rodrigues, J. P.; Alves, M. B.; Quim. Nova 2009, 32, 768; Alves, J. M. A.; Sousa, A. A.; da Silva, S. R. G.; Lopes, G. N.; Smiderle, O. J.; Uchôa, S. C. P.; Rev. Agroambiente on-line 2008, 2,57 .

6. Ahmed, W. A.; Salimon, J.; Eur. J. Sci. Res. 2009, 31, 429.

7. Haas, W.; Sterk, H.; Mittelbach, M.; J. Nat. Prod. 2002, 65, 1434.

8. Abd-Alla, H. I.; Moharram, F. A.; Gaara, A. H.; El-Safty, M. M. Z.; Naturforsch., C: J. Biosci. 2009, 64, 495; Ebuehi, O. A. T.; Okorie N. A.; Niger Q. J. Hosp. Med. 2009, 19, 200.

9. Hufford, C. D.; Oguntimein, B. O.; Lloydia 1978, 41, 161.

10. Rideout, J. A.; Ragasa, C.; Ngo, H. T.; AGGC Chem. Res. Commun. 2003, 16, 34 .

11. Ayanbempe, G. M.; Ojo, T. K.; Afolabi, E.; Opara, F.; Orsaah, S.; Ojerinde, O. S.; J. Clin. Lab. Anal. 2009, 23, 161.

12. Rahuman, A. A.; Gopalarkrishnan, G.; Venkatesan, P.; Geetha, K.; Parasitol. Res. 2008, 102, 867. 
13. Wang, Z. Y.; Du, Y. Q.; Qin, Y. Z.; Chen, J. F.; Quan, Z. M.; J. Southern Medical University 2009, 29, 1235.

14. Matos, A. P.; Leite, A. C.; Batista-Pereira, L. G.; Vieira, P. C.; Fernandes, J. B.; Da Silva, M. F. G. F.; Z. Naturforsch., C: J. Biosc. 2009, 64, 441.

15. Matos, A. P.; Nebo, L.; Vieira, P. C.; Fernandes, J. B.; Silva, M. F. G. F.; Rodrigues, R. R.; Quim. Nova 2009, 32, 1553.

16. van den Dool, H.; Kratz, P. D.; J. Chromatogr. 1963, 11, 463; Lytovchenko, A.; Beleggia, R.; Schauer, N.; Isaacson, T.; Leuendorf, J. E.; Hellmann, H.; Rose, J. K. C.; Fernie, A. R.; Plant Methods 2009, 5, 4.

17. Lazari, D. M.; Skaltsa, H. D.; Constantinidis, T.; Flavour Fragr. J. 2000, 15,7 .

18. Kasten, P. Jr.; Precetti, A. A. C. M.; Parra, J. R. P.; Rev. Agric. 1978, 53, 68.
19. Parra, J. R. P. In Controle microbiano de insetos; Alves, S. B., ed.; São Paulo, Editora Manole: São Paulo, 1986, p. 348-373.

20. Zar, J. H.; Biostatistical Analysis, Prentice-Hall Inc.: Englewood Cliffs, 1984.

21. Facundo, V. A.; Pollli, A. R.; Rodrigues, R. V.; Militão, J. S. L. T.; Stabelli, R. G.; Cardoso, C. T.; Acta Amazonica 2008, 38, 733; Jain, P. S.; Bari S. B.; Asian J. Plant Sci. 2010, 9, 163.

22. Moccelini, S. K.; da Silva, V. C.; Ndiaye, E. A.; de Souza Jr., P. T.; Quim. Nova 2009, 32, 131.

23. Christie, W. W.; Gas Chromatography and Lipids: a practical guide, The Oily Press.: Bridgwater, 1989.

24. Devanand, P.; Rani, P. U.; J. Biopest. 2008, 1, 170. 